\title{
Credit Constraints for Microfinance Sector in Pakistan, an Analysis of Internal and External Factors
}

\author{
Muhammad Mohsin Khan* \\ National Bank of Pakistan, Lahore- Pakistan \\ *E-mail address: mohsin_khan434@yahoo.com
}

\begin{abstract}
Microfinance is considered to be an effective tool for poverty alleviation, employment generation, income generation and income equality. It is a financial service provided to poor people who do not have any other source of funds or have access to financial services. The purpose of this research paper is to determine the credit constraints that are facing by microfinance sector in Pakistan. The data is collected through structured questionnaires from 250 respondents who are employees of MFBs/ MFIs keeping in view three broad categories of theoretical framework including internal factors having sub variables like operational cost, HR capacity, innovation and external factors having sub variables like competition, language, awareness as independent variables and a dependent variable having sub variable that is credit constraints for microfinance sector. Regression analysis has been used to determine the impact of independent variables i.e. internal and external factors on dependent variable that is credit constraints. The study found that there is a significant impact of internal and external factors on the credit constraints facing the microfinance sector. Based on the results it is recommended that concerned authorities should give due importance to all sub variables of internal and external factors in order to minimize the issue of credit constraints facing the microfinance sector.
\end{abstract}

Keywords: Microfinance; Credit Constraints; Internal factors; External factors

\section{INTRODUCTION}

Microfinance is a financial service provided to those who do not have any other source of funds or have access to financial services. Morduch (2000), explained microfinance as a type of financial service (credit) provided to the poor people that is to be repaid in small installments against the amount loaned to them. Microfinance is considered to be an effective tool for employment generation, social development all leading towards poverty alleviation. Pakistan though late starter in field of micro financing has achieved many milestones including establishment of PPAF (Pakistan Poverty Alleviation Fund), promulgation of microfinance ordinance, establishment of scheduled microfinance banks/MFIs and SBP microcredit guarantee facility. Currently there are 10 MFBs operating in Pakistan (Erum Zaidi, 2013) and various MFIs/ NGOs are also operating in Pakistan. But all these institutions either small or large only cater $9 \%$ of potential clients from total potential of $27 \mathrm{M}$ prospective borrowers (Pakistan Microfinance Network) due to credit constraints and this research article intends to highlight the issues that are leading towards credit constraints for microfinance sector. The main objectives of this research article is to highlight the issues of credit constraints for 
microfinance sector as there are about 10 microfinance banks and various MFIs and NGOs but still this sector is dependent on external support and also to provide some suggestions/ recommendations to cope with the problem of credit constraints issue. For fulfilling these research objectives the research questions are as follows;

oWhat are the major reasons of credit constraints facing the sector?

oAre the internal factors including human resource, operational costs, lack of innovative products, financial un-sustainability and deposit mobilization leads to credit constraints?

oAre the external factors including competition, language barrier, trust, illiteracy barrier and lack of awareness leads to credit constraints?

oAre the internal factors more crucial than external factors?

oAre the external factors more crucial than internal factors?

In the end it is concluded that by giving importance to all sub variables mentioned in the article, credit/ liquidity position of the sector can be improved.

\section{LITERATURE REVIEW}

Microfinance is a financial service provided to those who do not have any other source of funds or have access to financial services. Morduch (2000), explained microfinance as a type of financial service (credit) provided to the poor people that is to be repaid in small installments against the amount loaned to them. Otero (1999), defined microfinance as a financial service provided to low income groups.

Micro financing, worldwide is considered to be an effective tool for employment generation, women empowerment, social development all leading towards poverty alleviation.

Microfinance in Pakistan has followed an evolutionary path over the last four decades.

In the first phase microfinance services were in the form of government directed/subsidized credit schemes particularly in rural areas. In this phase Small Business Finance Corporation (SBFC), Youth Investment Promotion Society (YIPS), Self Employment Scheme (SES) were initiated by the government. In this phase government forced other financial institutions to provide concessionary financing especially to youth and business startups with the motive to promote microfinance industry. (Erum Zaidi, 2013)

In the second phase two microfinance institutions, Aga Khan Rural Support Program (AKRSP) and the Orangi Pilot Project (OPP) was established for providing microfinance services to poor clients, both projects were not operating with the profit motive as a result their outreach was not to the large extent due to credit constraints. Pioneers such as AKRSP and OPP had set the stage further taken forward by other Rural Support Programs. Microfinance involves financial intermediation. Some NGOs had taken up one side of this intermediation that is loans and left the other side that is deposit mobilization. While a few, including AKRSP not only provided loans but also mobilized savings from its clients to be deposited in commercial banks. The first step into microfinance by a regulated financial institution was made by a leasing company - Network Leasing Corporation (NLCL), established in 1995, specifically for providing micro leasing services to small businesses throughout Pakistan. (Erum Zaidi, 2013)

In the third phase that is by mid 1990's microfinance attracts tremendous interest from the donor community as a tool for poverty alleviation and with a promise of financial sustainability. The global microfinance industry started gaining momentum and best practices started taking shape. (Erum Zaidi, 2013) 
In the last decade the entry of regulated financial institutions such as microfinance banks, microfinance institutions, government supported programs, proclamation of Microfinance Ordinance 2001; SBP's Prudential Regulations entered the microfinance arena. Mostly urbanbased microfinance programs also came up in major cities of Pakistan. Regulatory structures started taking shape, thus making a new microfinance institutional structure. (Erum Zaidi, 2013)

The establishment of Khushali Bank Ltd in 2000 and promulgation of microfinance ordinance 2001 depicts the significant work in microfinance sector because microfinance ordinance give rise to MFBs, providing services specifically to poor people further microfinance ordinance gives many advantages to MFBs over other NGOs/ MFIs including, not just providing credit- only products as MFBs are able to mobilize the deposits thus making a continuous source of funding for them, creating strong institution having effective risk management policies and strong governance. Currently there are 10 MFBs operating in Pakistan (Erum Zaidi, 2013) and various MFIs/ NGOs are also operating in Pakistan. But all these institutions either small or large only cater $9 \%$ of potential clients from total potential of $27 \mathrm{M}$ prospective borrowers (Pakistan Microfinance Network). Though this sector is facing numerous challenges, but credit constraints is one of the major challenges this sector is facing.

Rauf and Tahir (2009), concluded from their research that MFBs/ MFIs adopted extensive growth strategy instead of intensive growth strategy which resultantly give rise to high investment costs in the form of brick and mortar branches, infrastructure development, increase in branch staff etc due to which sector becomes dependent on subsidies and their growth and expansion is subject to availability of donor funds/ external support moreover due to adoption of extensive growth strategy this sector is not financially or operationally sustainable. Hirchland (2003), concluded that due to MFBs' focus on development of physical infrastructure it leads to high operating costs and resultantly prospective borrowers to the larger extend cannot be served, because major portion of budget is utilized for its operational setup.

Befekadu B. Kerata revealed lack of trust of donors on MFBs, because MFBs are not financially or operationally sustainable and resultantly there is a lack of access to finance for MF sector. According to Microfinance Information Exchange (MIX, 2006), MFIs are facing high operating costs and one third of MFBs in Pakistan are financially sustainable. Sobia Mesiya (2013), pointed out that due to increase in population and especially poor, demand and supply gap of funds is widening, demand is high but supply is exhausted further there is a intense competition among MFBs/ MFIs that who will get the maximum share of funds as well as the growing no. of branchless banking providing basic banking services to far flung areas of country making deposit base for MFBs in danger and due to depressed sustainability and financial position of MFBs there will be a severe credit rationing in future. She also highlighted the fact that funds that are available for MF sector will be utilized soon so microfinance should be prepared for credit constraints. Mohsin and Basharat (2013) revealed that Micro Credit Guarantee Facility (MCGF) is expected to be fully utilized in near future while Pakistan Poverty Alleviation fund is already dying up thus showing the alarming situation for the microfinance sector as far as liquidity position is concerned.

Marulanda (2005) pointed out that there is intense competition between microfinance sector and other commercial banks which is depicting another reason for credit constraints for the sector. Sulaiman D. Muhammad (2010), while identifying the challenges and opportunities of microfinance in Pakistan stated that due to emergence of more and more MFBs/ MFIs the competition among them has been increased and now customers are demanding new and 
diversified products that lead to high transaction costs, low margins and resultantly lesser profits. UNEP Finance Initiative (2008), stated that investors and other commercial banks are either risk aversive or skeptical regarding the microfinance sector and donations/ financial assistance to them is not their first priority, further the same study also pointed out that the availability of donor funds at low interest rates, this frustrate the investors because while demand for microfinance is high but low interest rate is offered to micro entrepreneurs as a result of the large volume of donor subsidized funding.

Rauf and Mehmood (2009), revealed that MFBs/ MFIs have one dimensional focus and that is credit only products due to which MFBs/ MFIs are facing low savings mobilization further SBP (2011) highlighted that MFBs are still credit- driven, up till now no significant deposits have been raised by the sector on its own and are also unable to penetrate in the market to offer other banking services including home remittances, money transfer etc. Kanwal Bukhary (2010) raised the point that $56 \%$ of the adult population in Pakistan does not have access to financial services as a result of which it leads to the fact that major focus of microfinance sector is urban area and not the rural area resultantly the sector is facing the problem of liquidity.

Lack of institutional capacity/ proper management skills, illiteracy and lack of demanddriven products for the target customers also increase the issue of credit constraints for microfinance sector. Mr. Yunus in 2003 also pointed out that due to MFIs non- absorptive capacity they are blamed to be dependent on subsidies further he also stated while delivering his speech on millennium development goal (2003), that due to lack of encouragement in creating new financial institutions, absence of regulatory framework for microfinance sector, barriers in reaching the deposits and lack of clarity regarding the true concept of micro finance, money is not available and the sector is facing the problem of credit constraints. Ishrat Hussain (2011) also highlighted that MFIs are focusing on credit driven products and not on other opportunities including deposit mobilization etc. Erum Zaidi (2013) also revealed the same fact by stating that deposit mobilization growth is slow further capital adequacy requirements set by SBP leads to credit constraints for the sector. Christian and Rosenberg (2000), concluded that due to requirement of capital adequacy ratio and cash reserve requirement for MFBs imposed by central bank of the country the microfinance sector is facing the problem of credit constraints because major portion of their liquidity is utilized there.

Khushali Bank Limited (2010), highlighted that due to lack of branches in rural areas deposit base is not increasing. According to SBP (2013), the reasons for low deposit base for MFBs are limited capacity of human resource and credit only products. SBP also added that due to easy accessibility of donor funds make MFBs in comfort zone. Dr. Yunus also stated in 2003 that if there is continuous access of subsidized loans/ external support for microfinance sector then this sector cannot able to stand alone in the market environment with full financial and operational strength as Nikhil (2011) concluded that microcredit facilities can be provided to poor people without the assistance of any subsidies or external support if the sector is regulated effectively.

Limited capacity of HR is also very important factor for the low deposit base of the sector Ishrat Hussain (2011), pointed out regarding non- availability of skilled staff for microfinance. Sulaiman D. Muhammad (2010), highlighted the issue of limited Human Resource capacity in microfinance sector because this sector do not have adequate management capacity to run the microfinance institution in efficient way. Kanwal Bukhary (2010), pointed out that due to 
limited human resource capacity to make innovative and modern/ competitive products, micro finance sector is not growing to the desirable level and not increasing its deposit base.

Kanwal Bukhary (2010) also stated that as compared to commercial banks, the age of MFBs/ MFIs is small and it requires time and public confidence to become a people choice for deposit mobilization. The same fact has also been stated by Abnan and Mohsin that MFBs are at primary stages and due to lack of awareness among public this sector is facing high operating costs, further MFBs/ MFIs contains small deposits that is they are targeting the small deposits instead of larger ones as their $90 \%$ of the sample portfolio has adopted such practice. SBP in 2011 also highlighted this fact that due to new entrant relative to commercial banks, microfinance sector is not enjoying public confidence and trust. Erum Zaidi (2013), also endorses this fact that MFBs are at early stages and they require time to earn public confidence.

Mohsin and Basharat (2013) revealed that commercial banks categorized MFIs as manufacturing concerns rather than financial institutions due to which as per SBP PRs debt to these institutions cannot increase four times of equity of MFIs. According to SBP (2011), commercial banks are reluctant to provide funds to this sector due to their own tight monetary conditions.

Microfinance sector is facing credit constraints as well as low deposit mobilization due to illiteracy of prospective clients; these prospective clients are unaware and reluctant to understand the terms and conditions of microfinance services. SBP (2013) while identifying the challenges facing the microfinance sector stated that mostly unbanked population of Pakistan is illiterate and do not even know about their privileges due to which they are not able to get full benefit from microfinance services. Mario de Queiroz in 2006 revealed that due to language barrier MFIs are suffering with low deposit base because clients are not able to understand what type of services MFIs are offering. Ehsan and Asghar (2011), while identifying issues facing by MFBs stated language barrier as one of the major issues for growth of microfinance sector. Sibghatullah Nasir (2013) concluded that language barrier makes communication with the clients very difficult; due to this the policies regarding microfinance services are not easily understandable for the clients which may lead to another barrier in growth and expansion of MICROFINANCE sector.

MFBs/ MFIs are dependent on subsidies and grants due to the fact that up till now this sector is not sustainable financially as pointed out by Zaigham with her co- authors (2011), that MFBs are not capable to utilize their assets in an effective manner due to which they are incapable for more credit generation and generating more profits. UNEP Finance Initiative (2008), pointed out that due to presence of no. of donors that are providing donations and financial assistance to microfinance sector, this sector becomes unattractive to private investors/ free markets and it leads to barriers to long term financial sustainability of the sector.

Syeda along with the co- researchers (2013) concluded that Pakistani MFIs are not financially sustainable due to high loan losses, customer overlapping, small client base and limited management capacity resultantly they are not capable for more credit generation and deposit mobilization. Sibghatullah Nasir (2013), also pointed out that one of the barriers in growth of microfinance sector is the increased number of defaulted loans that resultantly make impact on sustainability of the sector.

Rehman (1998) concluded that due to lack of proximity microfinance sector is facing credit constraints.

The review of literature about microfinance sector of Pakistan reveals that to know the issues relating to credit constraints for microfinance sector is relatively new because previous 
studies for this sector are about the impact of micro financing in alleviating the poverty in Pakistan. This paper will specifically focus on the issues that give rise to credit constraints for micro finance sector.

\section{THEORETICAL FRAMEWORK}

\section{Independent Variables}

\section{Dependent Variable}

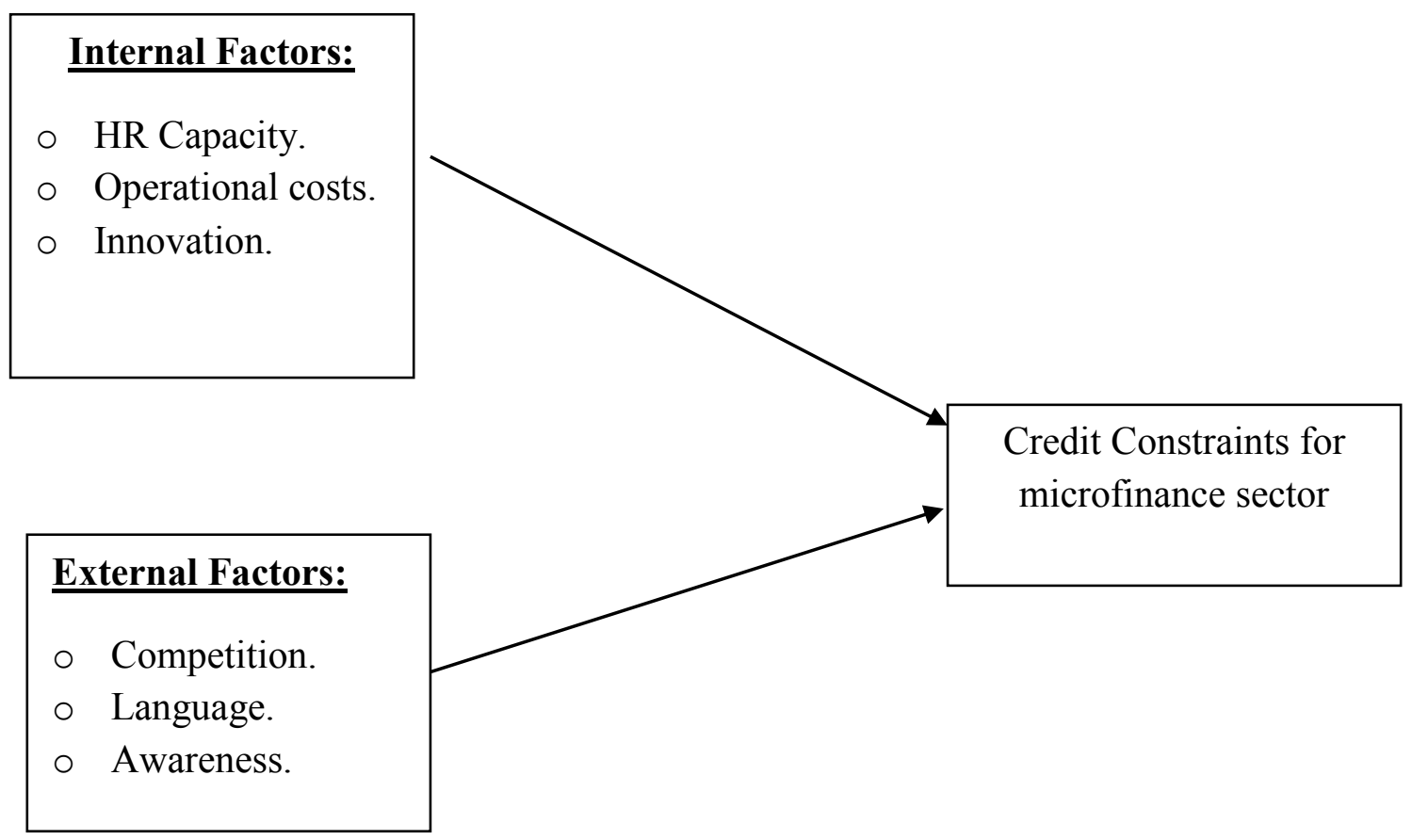

\section{RESEARCH METHOLODGY}

Theoretical framework was developed on the basis of literature review. Keeping in view the theoretical framework the study requires the collection of data through questionnaires.

\subsection{Sample}

To fill the questionnaires a sample of 270 respondents which are employees of MFBs/ MFIs were chosen using convenience sampling method. From the sample of 270 respondents 250 responses have been received back and data is analyzed based on these responses.

\subsection{Questionnaire}

A questionnaire was developed on the basis of literature review and theoretical framework. Technique used in questionnaire was likert scale (1-5) from strongly disagree to strongly agree. The reliability of the questionnaire was carried out on SPSS 20 and results were found through regression analysis. 


\subsection{Methodology}

Based on the theoretical framework, main variables (independent and dependent variable) are divided into 03 categories i.e. Internal factors, External factors (both are independent variables) and a dependent variable. These three variables have further sub variables (already mentioned on theoretical framework).

Regression analysis has been conducted to determine the impact of independent variables i.e. internal and external factors on credit constraints issues of microfinance sector.

Table 1. Demographics profiles of Respondents.

\begin{tabular}{|c|c|c|}
\hline Respondents' Demographics & & Frequency \\
\hline \multirow{2}{*}{ Gender $(\mathbf{N}=\mathbf{2 5 0})$} & Male & 165 \\
\hline \multirow{3}{*}{ Age $(\mathbf{N}=\mathbf{2 5 0 )}$} & Female & 85 \\
\cline { 2 - 3 } & 25 years or below & 30 \\
\cline { 2 - 3 } & More than 25 but less than 30 & 47 \\
\cline { 2 - 3 } Qualification $(\mathbf{N = 2 5 0 )}$ & 30 but less than 35 & 68 \\
\cline { 2 - 3 } & 35 but less than 45 & 66 \\
\cline { 2 - 3 } & Above 45 & 39 \\
\hline & Matric & 29 \\
\hline & Intermediate & 50 \\
\hline & Graduation & 120 \\
\hline & Masters & 46 \\
\hline Experience $(\mathbf{N}=\mathbf{2 5 0 )}$ & Above Masters & 5 \\
\hline & Less than 1 year & 37 \\
\hline & 1 or more but less than 5 years & 57 \\
\hline & 5 or more but less than 10 years & 120 \\
\hline & More than 10 years & 36 \\
\hline
\end{tabular}

\section{EMPIRICAL FINDINGS}

In this research paper regression analysis has been used to check the impact of independent variables that is internal factors (HR capacity, operational cost, innovation) and the external factors (competition, language and awareness) on the dependent variable that is credit constraints and following is the result of regression analysis.

Table 2. Empirical Findings.

\begin{tabular}{|c|c|c|c|c|c|c|}
\hline & & \multicolumn{2}{|c|}{$\begin{array}{c}\text { Un standardized } \\
\text { Coefficients }\end{array}$} & $\begin{array}{c}\text { Std. } \\
\text { Coefficients }\end{array}$ & \\
\hline Sr. No. & Variables & B & Std. Err & Beta & T values & $\begin{array}{c}\text { Sig. } \\
\text { Values }\end{array}$ \\
\hline 1 & HR Capacity. & -0.136 & 0.057 & -0.179 & -2.373 & 0.018 \\
\hline
\end{tabular}




\begin{tabular}{|c|c|c|c|c|c|c|}
\hline 2 & $\begin{array}{c}\text { Operational } \\
\text { Cost. }\end{array}$ & 0.206 & 0.061 & 0.234 & 3.362 & 0.001 \\
\hline 3 & Innovation. & 0.150 & 0.047 & 0.198 & 3.168 & 0.002 \\
\hline 4 & Competition. & 0.135 & 0.047 & 0.149 & 2.842 & 0.005 \\
\hline 5 & Language. & 0.266 & 0.060 & 0.316 & 4.432 & 0.000 \\
\hline 6 & Awareness. & 0.345 & 0.035 & 0.450 & 9.969 & 0.000 \\
\hline
\end{tabular}

* Dependent Variable: Credit Constraints.

Result of regression analysis (mentioned above) shows that the effect of independent variables on dependent variable is significant as all the sig values of variables (both of internal and external factors) have values less that 0.05 which means that all these variables have a significant positive relationship with the dependent variable that is credit constraints for microfinance sector and the dependent variable is affected by these variables.

Table 3. Other Statistical Tests.

\begin{tabular}{|c|c|c|c|}
\hline $\mathrm{R}^{2}$ & $58.7 \%$ & F- Statistics & $\begin{array}{c}57.614 * \\
\text { *sig value is } 0.000\end{array}$ \\
\hline
\end{tabular}

Value of adjusted $\mathrm{R}^{2}(58.7 \%)$ shows that internal and external factors explain $58.7 \%$ percent variation in dependent variable that is credit constraints for microfinance sector and rest $41 \%$ variation in the dependent variable is due to all other variables that are not included in this theoretical framework that also leads to further research in this particular research problem. Ftest $(\mathrm{F}$ Statistic $=57.614$ with sig value 0.000$)$ shows that joint effect of both independent variables on credit constraints- a dependent variable is significant and my model is good fit.

The results of this research article support the findings of Sulaiman D. Muhammad (2010), Narrowing the gap- A survey of the barriers and drivers to commercial microfinance in Africa by UNEP (2009), Budding Issues In Microfinance Sector Of Pakistan by Shan E Ahmad Syedah, Batool S. Anum, Anwar Zeshan, Khan M. Kaleem (2013), Microfinance in India: Contemporary Issues and Challenges by Sibghatullah Nasir (2013)

\section{SUGGESTIONS AND RECOMMENDATIONS}

Based on the data analysis and empirical findings it has been observed that all sub-variables of internal and external factors have a significant positive relationship with the credit constraints facing the microfinance sector. Here are some of the suggestions/ recommendations to cope with the issue of credit constraints.

oPeriodical trainings should be imparted to the employees so that they can be able to work effectively. By periodical trainings regarding latest trends in microfinance, employees will be able to deal with their clients more efficiently and effectively. ((Ishrat Hussain 2011, Suleman D. Muhammad 2010, Kanwal Bukhari 2010)

oTo cope with the issue of credit constraints microfinance sector should make innovative products, as many MFBs/ MFIs are just providing credit only products. The sector should encourage innovations so that they can be able to attract more deposits. (Kanwal Bukhari 2010) 
oMicrofinance sector should make necessary steps preferably 'to adopt intensive growth strategy' in lowering down their operational costs. As the major portion of their credit is engaged in meeting their operational costs. (Shahnaz A. Rauf and Tahir Mahmood (2009), Hirchland (2003), Sibghatullah Nasir (2013)

oMicrofinance sector should make every effort for mobilization of deposits as this sector is dependent heavily on external support including subsidies etc. By offering various innovative savings products and not limited to credit only products they can be able to increase their deposits and can be self sufficient. (Dr. Yunus, 2003, Rauf and Tahir 2009)

oAn aggressive marketing of the products and the organization itself is very necessary for getting the awareness and overall trust for the organization. As one of the major reasons for low deposit mobilization is the lack of trust among people/ prospective clients. (SBP 2011, Erum Zaidi 2013, Kanwal Bukhari 2010, Abnan \& Mohsin 2013)

oMFBs/ MFIs should publicize their product and services in their prospective clients' native languages so that they can better understand regarding services provided by the MFBs/ MFIs. (SBP 2013, Mario de Queiroz 2006, Sibghat Ullah Nasir 2013)

\section{CONCLUSION}

Microfinance is a financial service provided to those who do not have any other source of funds or have access to financial services. This study was related to the issues relating to credit constraints which are facing by microfinance sector. The data is collected through questionnaires keeping in view the three broad categories of theoretical framework including internal and external factors having sub variables as independent variables and a dependent variable that is credit constraints for microfinance sector. Regression Analysis has been used and it is found that all sub- variables of internal and external factors have a significant positive relationship with the credit constraints facing the microfinance sector. By giving importance to all sub variables we can expect a considerable improvement in credit/ liquidity position of the sector.

\section{References}

[1] Otero M. and E. Rhyne (2006), Microfinance through the Next Decade: "Visioning the Who, What, Where, When, and How" ACCION International.

[2] Sulaiman D. Muhammad, Microfinance Challenges and Opportunities in Pakistan, European Journal of Social Sciences - Volume 14, Number 1 (2010)

[3] Microfinance Review by Business Recorder (2013).

[4] Narrowing the gap- $A$ survey of the barriers and drivers to commercial microfinance in Africa by UNEP (2009)

[5] Ishrat Hussain (2011), Key regulatory tools for Promotion of access to finance.

[6] Aban and Mohsin (2010), Significance of small deposits for Microfinance Providers.

[7] Kanwal Bukhary (2010), Microfinance in Pakistan- Policy, sector updates and key issues. 
[8] Pakistan Microfinance Network (2013), Funding industry growth- growing beyond numbers.

[9] Dr. Yunus (2011), Expanding Microcredit Outreach To Reach The Millennium Development Goal- Some Issues For Attention.

[10] Dr. Shamshad Akhtar 2007, Building Inclusive Financial System in Pakistan.

[11] Shan E Ahmad Syedah, Batool S. Anum, Anwar Zeshan, Khan M. Kaleem (2013), Budding Issues In Microfinance Sector Of Pakistan.

[12] Sibghatullah Nasir (2013), Microfinance in India: Contemporary Issues and Challenges. 